\author{
Stanisława Talaga, Marta Dyrcz, \\ Bogumiła Lubińska-Żądło, Aleksandra Kiełtyka \\ Podhalańska Państwowa Wyższa Szkoła Zawodowa w Nowym Targu
}

\title{
JAKOŚĆ ŻYCIA OSÓB STARSZYCH UCZESTNICZĄCYCH W ZAJECCIACH UNIWERSYTETU TRZECIEGO WIEKU
}

\begin{abstract}
Quality of life of older people participating in the activities of the university of the third age. In connection with the phenomenon of population aging and the creation of a new social policy, a new direction in pedagogics called andragogy, or sub-discipline dealing with adult education, was created. The task of adult education has taken over Universities of the Third Age, pursuing such goals as: continuing education, socio-cultural activation, physical mobilization and dissemination of gerontological proficiency among participants. The aim of this study is to compare the quality of life of people over 60 years old, studying at the University of the Third Age, with people who do not participate in any seniors' occupations and live exclusively in their own home environment. The study used the diagnostic survey method. As a research tool, a questionnaire was used for the own questionnaire containing 22 questions, the Oswestry Questionnaire and The World Health Organization (WHOQOL) - BREFF.
\end{abstract}

Jakość życia osób starszych uczestniczących w zajęciach uniwersytetu trzeciego wieku. W związku z zjawiskiem starzenia się społeczeństwa i tworzeniem nowej polityki społecznej powstał nowy kierunek w pedagogice zwany andragogiką, czyli subdyscyplina zajmującą się kształceniem dorosłych. Zadanie kształcenia dorosłych przejęły uniwersytety trzeciego wieku, realizując takie cele jak: edukacja ustawiczna, aktywizacja społeczno-kulturowa, aktywizacja ruchowa oraz szerzenie wśród uczestników gerontologicznej profilaktyki. Celem niniejszej pracy jest porównanie jakości życia osób po 60. roku życia, studiujących na uniwersytecie trzeciego wieku, $\mathrm{z}$ osobami nieuczestniczącymi w żadnych zajęciach dla seniorów i bytujących wyłącznie we własnym środowisku domowym. W badaniu zastosowano metodę sondażu diagnostycznego. Jako narzędzie badawcze 
posłużył kwestionariusz ankiety własnego autorstwa zawierający 22 pytania, Kwestionariusz Oswestry oraz The World Health Organization Quality of Life (WHOQOL) - BREFF.

Keywords university of the third age, adult education, old age, andragogy, quality of life uniwersytet trzeciego wieku, edukacja dorosłych, starość, andragogika, jakość życia

Biorąc pod uwagę sytuację demograficzną w Polsce oraz w Europie, warto poruszyć temat, jakim jest starość: co ze sobą niesie, i co zrobić, by przełamać panujące wszechobecnie stereotypy na jej temat. Z badań naukowców prowadzonych już kilkadziesiąt lat temu wynikało, że odsetek osób w wieku powyżej 65 lat znacznie wzrośnie. Głównym powodem tego zjawiska w Polsce są emigracje ludzi młodych, rozwój medycyny oraz spadek liczby urodzeń ${ }^{1}$.

Jak wiadomo wiek każdego z nas jest wyznacznikiem życia społecznego. Młodzi ludzie piętnują ludzi starszych, postrzegając ich jako nieatrakcyjnych, schorowanych i przemądrzałych. Często nie chcą ich angażować we własne życie, uważając, że ich miejsce jest w domach starców. Tym stereotypom ulegają także działacze polityki społecznej, tworząc bariery dla ludzi starszych, często zapominając, że starzenie się dotyka każdego z nas indywidualnie, nie zważając na rasę czy płeć ${ }^{2}$.

Pod koniec lat 90. XX wieku Światowa Organizacja Zdrowia (WHO) podjęła próbę pokazania starości i procesu starzenia się w zupełnie innym świetle. Wprowadziła pojęcie „aktywnego starzenia”, które ma na celu poprawę jakości życia podczas procesu starzenia ${ }^{3}$.

Poszczególne etapy w życiu warunkują determinanty wpływające na jego jakość, wiąże się to $\mathrm{z}$ odmiennymi potrzebami każdego z nas, w zależności od wieku. Tak też jest w okresie starości, w której jednym z najważniejszych determinantów jakości życia stał się stan zdrowia. Jak powszechnie wiadomo, w raz z upływem lat pogarsza się kondycja psychofizyczna, która utrudnia czynności związane z codziennym funkcjonowaniem, co dla wielu osób w podeszłym wieku jest trudne do zaakceptowania ${ }^{4}$.

Kolejnymi aspektami wpływającymi na standard życia osób w podeszłym wieku są aktywność życiowa (jej brak prowadzi do odczuwania pustki i poczucia bezużyteczności) ${ }^{5}$ oraz uwarunkowania związane ze stanem psychologicznym (optymizm życiowy). Pozytywne podejście do życia jest jednym z czynników determinujących

1 M. Mossakowsska, A. Więcek, P. Błędowski, Aspekty medyczne, psychologiczne, socjologiczne, i ekonomiczne starzenia się ludności w Polsce, Poznań 2012, s. 11-12.

2 J. Trempała, L. Zając-Lamparska, Postawy wobec osób starszych: różnice międzypokoleniowe, „Przegląd Psychologiczny" 50 (2007) 4, s. 448-451.

3 A. Richert-Kaźmierska, M. Forkiewicz, Kształcenie osób starszych w koncepcji aktywnego starzenia się, Gdańsk 2013, s. 128-130

4 A. Ostrzyżek J. T. Marcinkowski, Wymiary jakości życia w podeszłym wieku, „Problemy Higieny i Epidemiologii” 90 (2009) 4, s. 465-467.

5 H. Zielińska-Więczkowska, K. Kędziora-Kornatowska, Determinanty satysfakcji życiowej w późnej dorosłości - w świetle rodzimych doniesień badawczych, „Psychogeriatria Polska” 7 (2010) 1, s. 13-15. 
wysiłek potrzebny do realizacji wyznaczonych sobie celów, ale także znacznie ułatwia zaakceptowanie nowych sytuacji życiowych ${ }^{6}$.

Poczucie koherencji to kolejny ważny element wpływający na ocenę standardu życia. Pojęcie to składa się z poczucia zaradności, sensowności i zrozumiałości wydarzeń zachodzących w życiu. Ma ono znaczący wpływ na radzenie sobie ze stresem - im wyższe poczucie koherencji ma człowiek, tym lepiej radzi sobie w stresujących sytuacjach oraz lepiej radzi sobie ze złymi emocjami, jakie im towarzyszą. Mniejsza podatność na stres ma związek z częstotliwością występowania różnych dolegliwości zdrowotnych, także z występowaniem stanów depresyjnych ${ }^{7}$.

Kolejnym wyznacznikiem zadowolenia z życia seniorów jest wsparcie społeczne, które odbywa się na czterech różnych szczeblach (wsparcie emocjonalne, udzielanie informacji i nabywanie nowych umiejętności, dostarczanie korzyści materialnych, nauka radzenia sobie w trudnych sytuacjach) ${ }^{8}$. Starszych ludzi, którzy cieszą się dużym wsparciem ze strony społeczeństwa, cechuje mniejsza podatność na stany depresyjne czy obniżenie ryzyka śmierci. Istnieje jednak zjawisko odwrotne, kiedy to zbyt duże wsparcie prowadzi do wyręczania we wszystkim osób starszych, co wzbudza w nich poczucie braku samodzielności i zaradności ${ }^{9}$. Warto również wspomnieć o wsparciu najbliższej rodzinny. Relacje, jakie łączą rodziców z dziećmi, mają znaczący wpływ na satysfakcję życiową w okresie ich starości. Brak dzieci lub złe stosunki z nimi w okresie późnej dorosłości powodują znaczny wzrost odczucia samotności i niskiej jakości życia ${ }^{10}$.

Kolejnym determinantem mającym wpływ na jakość przeżywania starości jest aktywność fizyczna, zarówno w młodości, jak i w późnym wieku. Dieta oraz sport często dodają osobom starszym pewności siebie, ułatwiają nawiązywanie kontaktu z innymi ludźmi, co również podnosi standard ich życia ${ }^{11}$.

Na jakość życia składają się: dobrostan społeczny, stan emocjonalny, materialny, stan zdrowia oraz zadowolenie ze zdolności do pracy. Nie ma jednak uniwersalnej definicji tego pojęcia. W 1992 roku WHO zdefiniowała jakość zdrowia jako subiektywną ocenę pozycji życiowej człowieka, uwzględniając wyznawane wartości, stosunki społeczne i kulturę, w której żyje. Ponadto, dokonując takiej oceny, należy wziąć pod uwagę warunki ekonomiczne, stan zdrowia w rozumieniu holistycznym, czynność zawodową oraz relacje międzyludzkie ${ }^{12}$.

6 M. Zadworna-Cieślak, N. Ogińska-Bulik, Zachowania zdrowotne osób $w$ wieku senioralnym - rola optymizmu, „Psychogeriatria Polska” 10 (2013) 4, s. 145-147.

7 M. Pasik, Wyznaczniki jakości życia u osób $w$ wieku emerytalnym, „Acta Univeritatis Lodiensis Folia Psychologica” (2005) 9, s. 71-72.

8 A. Głębocka, M. Szarzyńska, Wsparcie społeczne a jakość życia ludzi starszych, praca oryginalna, „Gerontologia Polska” 13 (2005) 4, s. 255-256.

9 E. Wojtyna, M. Dosiak, J. Życińska, Wpływ wsparcia społecznego na przebieg zaburzeń depresyjnych u pacjentów w podeszłym wieku, „Psychogeriatria Polska” 4 (2007) 1, s. 18-19.

10 P. Izdebski, A. Polak, Bilans życia i poczucie koherencji osób starszych $w$ zależności od ich aktualnej sytuacji życiowej, „Gerontologia Polska” 13 (2005) 3, s. 188-189.

11 A. Marchewka, M. Jungiewicz, Aktywność fizyczna $w$ młodości, a jakość życia w starszym wieku. „Gerontologia Polska” 16 (2008) 2, s. 127-129.

12 J. Grzegorczyk, A. Kwolek, K. Bazarnik, Jakość życia osób mieszkających w domach pomocy społecznej i słuchaczy uniwersytetu trzeciego wieku, „Przegląd Medyczny Uniwersytetu Rzeszowskiego” (2007) 3, s. 225-226. 
W medycynie badania nad jakością życia rozwinęły się wraz z jej postępem, kiedy umieralność pacjentów z powodu wielu chorób zmalała, a długość życia znacznie wzrosła. Tematem badań stała się kwestia, jak poprawić standard życia osób starszych oraz osób z chorobami przewlekłymi. Obecnie stanowi to większe wyzwanie niż samo ratowanie życia. Wprowadzenie pojęcia „jakości życia” do medycyny pozwoliło na dokładniejszą ocenę pracy lekarzy i funkcjonowania całej służby zdrowia oraz przywróciło zasadę holistycznego traktowania pacjenta ${ }^{13}$.

W związku ze zjawiskiem starzenia się społeczeństwa i tworzeniem nowej polityki społecznej powstał w pedagogice nowy kierunek zwany andragogiką, czyli subdyscyplina zajmującą się kształceniem dorosłych. Dobrym momentem do wznowienia edukacji jest przejście na emeryturę, które wiąże się ze zwiększeniem ilości wolnego czasu. Ułatwieniem jest także odmienne w tym wieku podejście do nauki, ponieważ pozwala na wybranie dziedziny, tematyki, jaka w danym momencie jest dla nas interesująca uczymy się wtedy dla siebie i dla własnej przyjemności, a nie z konieczności ${ }^{14}$.

Pierwsze uniwersytety w Polsce ukierunkowane na ludzi w starszym wieku powstały w 1976 roku - były to instytucje otwierane w dużych miastach przy działających uczelniach wyższych. W ramach programu edukacyjnego placówki te oferują wachlarz kursów, seminariów, lektoratów oraz możliwość przynależności do kół zainteresowań bez ograniczeń wiekowych dla tych, którzy czas emerytury chcą wykorzystać w sposób aktywny. Według przeprowadzonych badań największą popularnością UTW cieszą się wśród kobiet, które stanowią 90 proc. wszystkich słuchaczy ${ }^{15}$.

Uniwersytet trzeciego wieku ma określone cele działania, którymi są edukacja ustawiczna, aktywizacja społeczno-kulturowa, aktywizacja ruchowa oraz szerzenie wśród uczestników profilaktyki gerontologicznej ${ }^{16}$. Władze instytucji współpracują w środowisku lokalnym, w ramach rozwiązywania problemów społecznych. Polega to na organizowaniu wolnego czasu słuchaczy UTW z dziećmi, studentami, osobami niepełnosprawnymi czy innymi seniorami w celu pielęgnowania relacji międzypokoleniowych i wymiany wartości ${ }^{17}$.

Podsumowując, działalność UTW jest pewnego rodzaju formą łamania stereotypów na temat starości - UTW jest jedyną instytucją szerzącą profilaktykę gerontologiczną w Polsce na tak szeroką skalę. To przykład konstruktywnego podejścia do polityki społecznej, która za zadanie ma przeciwdziałać takim zjawiskom jak strach przed starością czy marginalizacją osób starszych przez ludzi młodych. W aspekcie naukowym

13 A. Trojanowska, Znaczenie badań nad jakością życia w medycynie, Praca poglądowa. „Zdrowie Publiczne" 121 (2011) 1, s. 100-102.

14 R. Kałużny, Aktywność edukacyjno-zawodowa seniorów formą zagospodarowania czasu na emeryturze, „Edukacja Dorosłych” (2014) 2, s. 79-90.

15 A. Bielawska, J. Pieścikowska, G. Bączyk i in., Uniwersytet trzeciego wieku-edukacja zawsze na czasie, „Nowiny Lekarskie” 81 (2012) 1, s. 80-82.

${ }^{16}$ K. Lubryczyńska, Warszawskie Uniwersytety Trzeciego Wieku, http://www.e-mentor.edu.pl/artykul/ index/numer/9/id/148 (25.11.2017).

17 B. Ziębińska, Uniwersytety Trzeciego Wieku - wybrane aspekty funkcjonowania organizacji, „Polityka Społeczna" (2009) 3, s. 21-22. 
skupienie tak dużej liczby starszych osób daje możliwość badań i poszerzania wiedzy gerontologicznej ${ }^{18}$.

\section{Cel pracy, material i metody}

Celem niniejszej pracy było porównanie jakości życia osób po 60. roku życia studiujących na uniwersytecie trzeciego wieku i osób nieuczestniczących w żadnych zajęciach dla seniorów i bytujących wyłącznie we własnym środowisku domowym.

$\mathrm{W}$ badaniu zastosowano metodę sondażu diagnostycznego. Za narzędzie badawcze posłużył kwestionariusz ankiety własnego autorstwa zawierający 22 pytania, Kwestionariusz Oswestry oraz The World Health Organization Quality of Life (WHOQOL) - BREFF.

\section{Charakterystyka BADANeJ GRUPy}

Badania przeprowadzone zostały na przełomie października i listopada 2016 roku na terenie Krakowa i okolic. Badaniem objęto osoby obu płci, w liczbie 136, mieszkające w mieście oraz na wsi. Kryterium doboru do grupy badawczej był wiek powyżej 60 lat, stan zdrowia niewymagający hospitalizacji, samowystarczalność w aspekcie funkcjonowania w życiu codziennym oraz uczestnictwo lub jego brak w zajęciach uniwersytetu trzeciego wieku.

\section{WYNIKI}

Badaniu poddano 136 osób starszych (w wieku 60 i więcej lat), kwalifikowanych do dwóch grup różniących się uczestnictwem w zajęciach uniwersytetu trzeciego wieku:

- grupa I - 86 osób starszych nieuczestniczących w zajęciach uniwersytetu trzeciego wieku,

- grupa II - 50 osób starszych uczestniczących w zajęciach uniwersytetu trzeciego wieku.

W obu badanych grupach przeważały kobiety (61,6 proc. grupa 1 i 66,0 proc. grupa 2 ).

Wiek badanych osób z grupy I zawierał się w przedziale 60-94 lat, średni wiek: 72 lata. W grupie II średni wiek wynosił 74,7 lat, a zakres wieku w tej grupie zawierał się między 62 a 96 lat.

18 W. Borczyk, W. Wnuk, Edukacja w starości i do starości, w: Strategie działania w starzejącym się społeczeństwie. Tezy i rekomendacje. Rzecznik praw obywatelskich, Warszawa 2012, s. 78-81. 
Na rycinie 1 przedstawiono wiek badanych osób w obu grupach. W grupie I najliczniejsza była grupa wiekowa 60-69 lat (48,8 proc.), a w grupie II najwięcej osób było w wieku 70-79 lat (46 proc.)

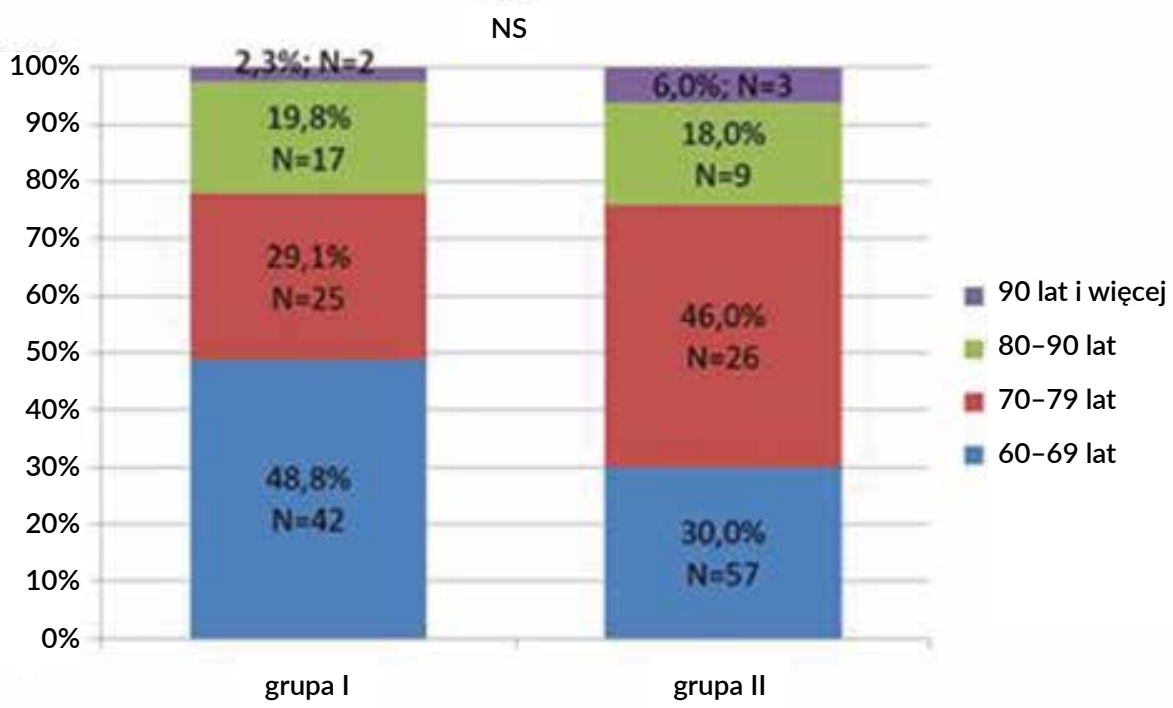

Ryc. 1. Wiek badanych osób. Źródło własne.

W grupie I przeważały osoby mieszkające na wsi (64 proc.), a w grupie II osoby mieszkające w mieście (78 proc.).

Obie badane grupy różniły się pod względem wykształcenia. W grupie II połowa badanych miała wykształcenie średnie, a druga połowa wyższe. W grupie I wykształcenie było bardziej zróżnicowane (zawodowe - 38,4 proc.; podstawowe - 31,4 proc.; średnie -17,4 proc.; wyższe $-12,8$ proc.).

Grupy nie różniły się pod względem aktywności zawodowej badanych osób. W obu pracowało nieco ponad 70 proc. badanych osób.

Rodzaj wykonywanej pracy różnicował statystycznie znamiennie $(\mathrm{p}<0,001)$ badane grupy. W grupie I ponad połowa $(65,4$ proc.) badanych wykonywała pracę fizyczną, a 22,2 proc. umysłową; w grupie II połowa badanych wykonywała pracę umysłową i dodatkowo 44 proc. badanych wykonywało pracę o charakterze mieszanym: umysłową/fizyczną.

Na ryc. 2 przedstawiono rozkład odpowiedzi na pytanie, z kim mieszka badana osoba. Nie różnicował on badanych grup. W grupie I samotnie mieszkało 23,3 proc. badanych, a w grupie II 28 proc. badanych (ryc. 2). 
NS



Ryc. 2. Z kim mieszkają osoby w badanych grupach. Źródło własne.

Kolejna rycina przedstawia zainteresowania. Sport, gry indywidualne lub zespołowe, robótki ręczne, czytanie książek, słuchanie radia czy oglądanie telewizji nie różnicowały badanych grup. W grupie II znamiennie $(\mathrm{p}<0,001)$ więcej osób niż w grupie I chodziło do kina, teatru lub opery. Natomiast w grupie I znamiennie $(\mathrm{p}<0,001)$ więcej osób niż w grupie II interesowało się przyrodą (ryc. 3).

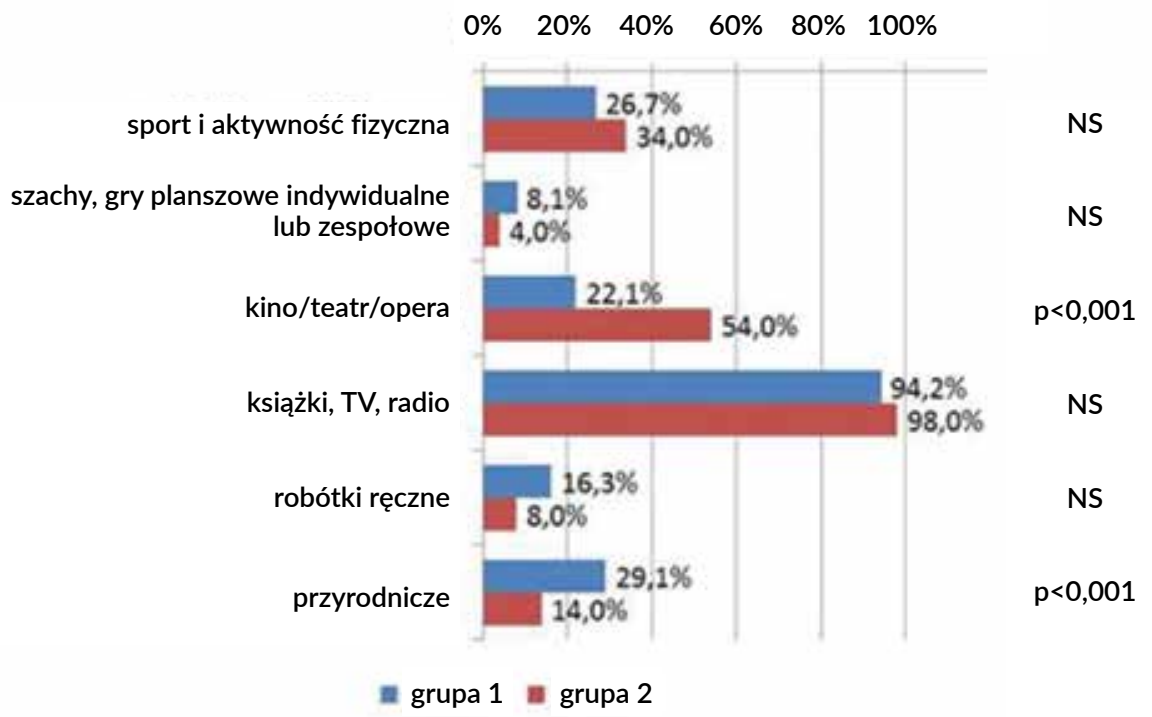

Ryc. 3. Poszczególne zainteresowania w obu grupach badanych. Źródło własne. 
Obie badane grupy różniły się znamiennie $(\mathrm{p}<0,001)$ pod względem sposobów spędzania czasu wolnego. W grupie I najczęstszym sposobem spędzania wolnego czasu było oglądanie telewizji (45,3 proc. badanych), następnie 23,3 proc. czytało książki, a 19,8 proc. spacerowało, podczas gdy w grupie II połowa badanych wypełniała czas wolny, czytając książki, 24,0 proc. spędzało czas z przyjaciółmi i rodziną, a 18 proc. oglądało telewizję.

Osoby z grupy I miały statystycznie znamiennie $(\mathrm{p}<0,001)$ ograniczone możliwości korzystania z zajęć lub spotkań dla osób starszych organizowanych w miejscu zamieszkania (36,0 proc.) w porównaniu $z$ osobami z grupy II (76,0 proc.).

W obu badanych grupach większość stanowiły osoby samowystarczalne niepotrzebujące w życiu codziennym pomocy ze strony rodziny bądź przyjaciół, instytucji społecznych lub państwowych. Pod tym względem badane grupy nie różniły się statystycznie znamiennie (ryc. 4).

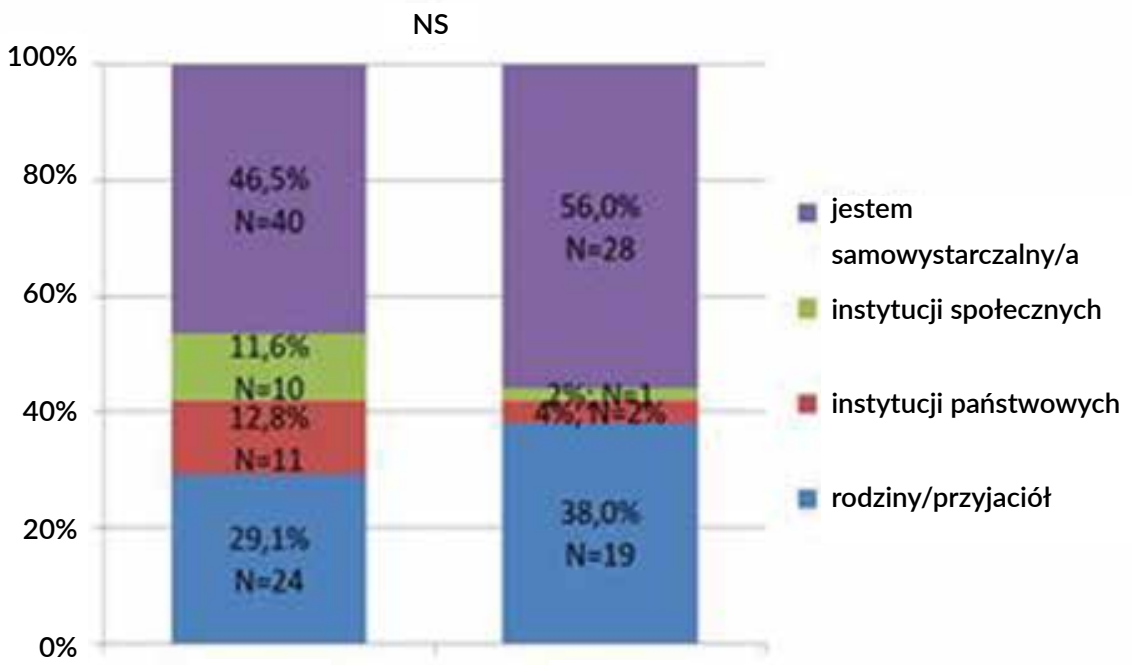

grupa I

grupa II

Ryc. 4. Korzystanie z pomocy w życiu codzienny przez osoby w badanych grupach. Źródło własne.

Badane grupy różniły się oceną kontaktów z innymi ludźmi. Prawie wszystkie osoby (94 proc.) z grupy II uważały, że rozmowa z innymi ludźmi poprawia im samopoczucie (tylko 1 osoba woli spędzać czas we własnym towarzystwie), podczas gdy w grupie I tak myślących osób było 66,3 proc. W tej grupie 24,4 proc. osób twierdziło, że nie ma okazji by spotykać się z ludźmi, a 8 (9,3 proc.) osób woli spędzać czas w swoim towarzystwie.

Odsetek osób charakteryzujących się otwartością i łatwością w nawiązywaniu kontaktów $\mathrm{z}$ innymi ludźmi był w obu badanych grupach wysoki i nie różnicował znamiennie badanych grup (I grupa 77,9 proc.; II grupa 80,0 proc.).

Badane grupy nie różniły się odsetkiem osób mających trudności w robieniu zakupów, wykonywaniu obowiązków domowych i w podróżowaniu. Czynności związane 
z obsługą komputerów lub urządzeń wyspecjalizowanych w konkretnych operacjach komputerami różnicowały badane grupy.

W grupie I znamiennie ( $\mathrm{p}=0,034)$ więcej osób ( 75,6 proc.) miało problemy z obsługą komputera lub korzystaniem z internetu niż w grupie II (58 proc.). Obsługa bankomatu, który jest wyspecjalizowanym terminalem komputerowym, stwarzała problemy 64 proc. osób z grupy I i tylko 22 proc. badanych z grupy II. W tym przypadku istotność różnić pomiędzy badanymi grupami występowała na poziomie $\mathrm{p}<0,001$ (ryc. 5).

Z wykresu zamieszczonego na ryc. 5 można wnioskować, że ogólnie osobom starszym spośród wybranych czynności dnia codziennego najmniej trudności sprawiały obowiązki domowe (10-16,3 proc.). Zakupy i podróżowanie stwarzały trudności na zbliżonym poziomie (38-48 proc.), natomiast korzystanie z komputerów stwarzało problem 50 proc. badanych (ryc. 5).

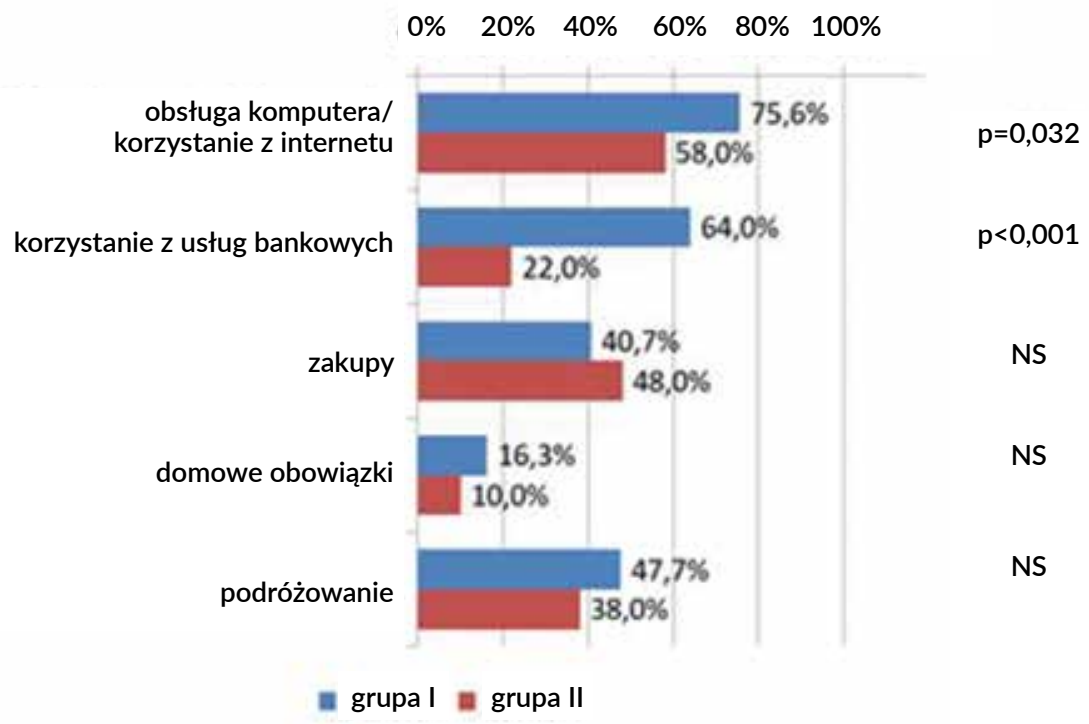

Ryc. 5. Trudności dnia codziennego występujące u osób w badanych grupach. Źródło własne.

Wśród badanej grupy I dyskryminację w życiu codziennym odczuwało prawie 75 proc. badanych, a w grupie II niewiele ponad 50 proc. badanych. Braku szacunku lub lekceważącego traktowania doświadczało 36 proc. osób z grupy I i 20 proc. z grupy II. Niechętnego udzielania pomocy w obsłudze nowoczesnych urządzeń doświadczyło 14 proc. badanych z grupy I. W grupie II takie odczucia miało 22 proc. badanych. W grupie I wyśmiewania doświadczyło 24,4 proc. badanych, a w grupie II o połowę mniej, bo 12 proc.

Obawy przed niepełnosprawnością w przyszłości występowały u 53,5 proc. osób z grupy I i 28 proc. z grupy II, co dawało różnice statystycznie istotne na poziomie $\mathrm{p}=0,004$. Samotności w przyszłości obawiało się po ok 30 proc. badanych w obu grupach. 
Obawy przed utratą atrakcyjności w przyszłości w obu grupach dotyczyły małej liczby badanych i nie stanowiły różnic pomiędzy badanymi grupami. Największe różnice pomiędzy badanymi grupami występowały w zakresie obaw dotyczących braku pieniędzy $(\mathrm{p}=0,003)$ i konieczności ciągłego siedzenia w domu $(\mathrm{p}<0,001)$. Braku pieniędzy częściej obawiały się osoby z grupy I, natomiast konieczności ciągłego siedzenia w domu częściej obawiały się osoby z grupy II. Różnice statystycznie znamienne $(\mathrm{p}=0,021)$ pomiędzy badanymi grupami występowały w obawach o stan zdrowia w przyszłości. Złego stanu zdrowia częściej obawiały się osoby z grupy I niż z grupy II (ryc. 6).

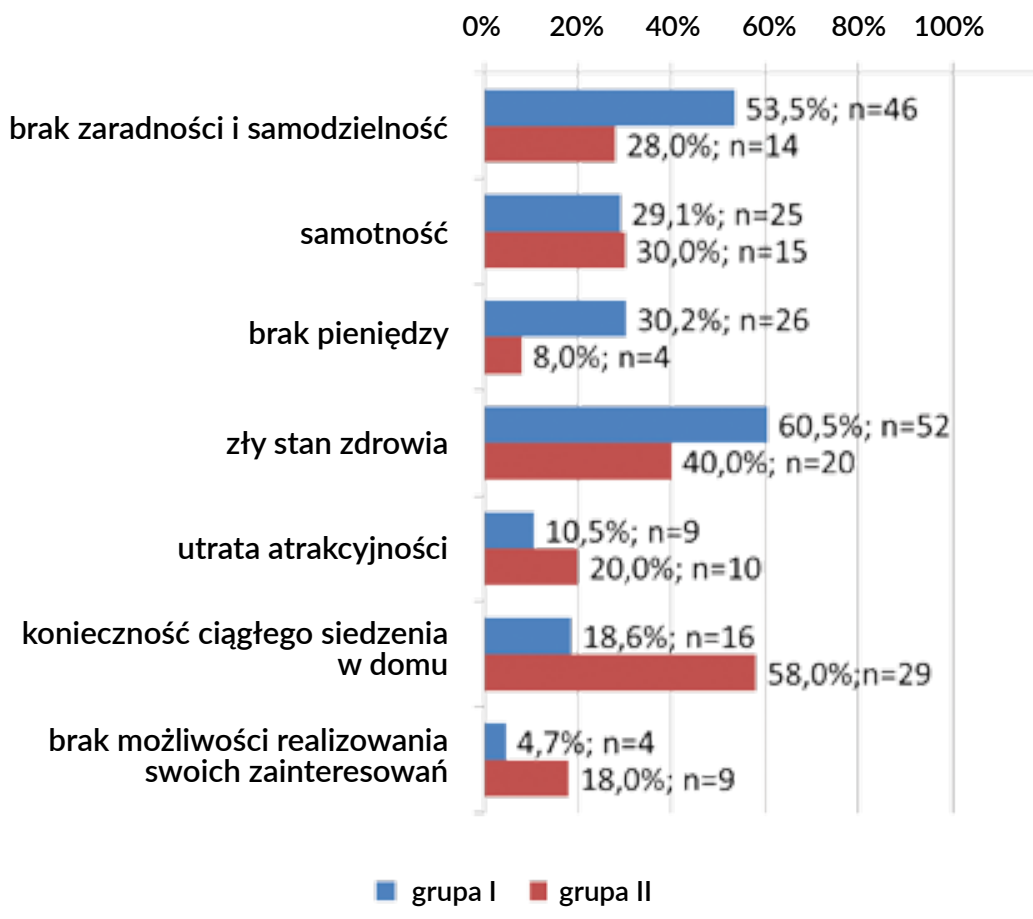

Ryc. 6. Obawy dotyczące przyszłości w ocenie osób z badanych grup. Źródło własne.

Zapytano badanych o to, czy chcieliby zmienić coś w swoim życiu. 32 osoby z grupy I pragnie coś zmienić w życiu, natomiast w grupie II - tylko 18 osób.

Stosunek do własnego wieku badanych osób jest różny w obu grupach. W grupie I 29 osób czuło się starzej niż były w rzeczywistości, w przeciwieństwie do II grupy, gdzie były to tylko 3 osoby. Wyniki dotyczące pytania, czy czują się młodziej, są bardzo zbliżone do siebie. W I grupie twierdząco odpowiedziały 24 osoby, a w grupie II - 26 osób.

Badane grupy różniły się znamiennie $(\mathrm{p}=0,035)$ pod względem częstotliwości występowania obniżonego nastroju. Codziennie lub kilka razy w tygodniu obniżony nastrój występował u ponad 50 proc. badanych z grupy I, podczas gdy w grupie II z taką częstotliwością obniżony nastrój występował tylko u 40 proc. badanych (ryc. 7). 


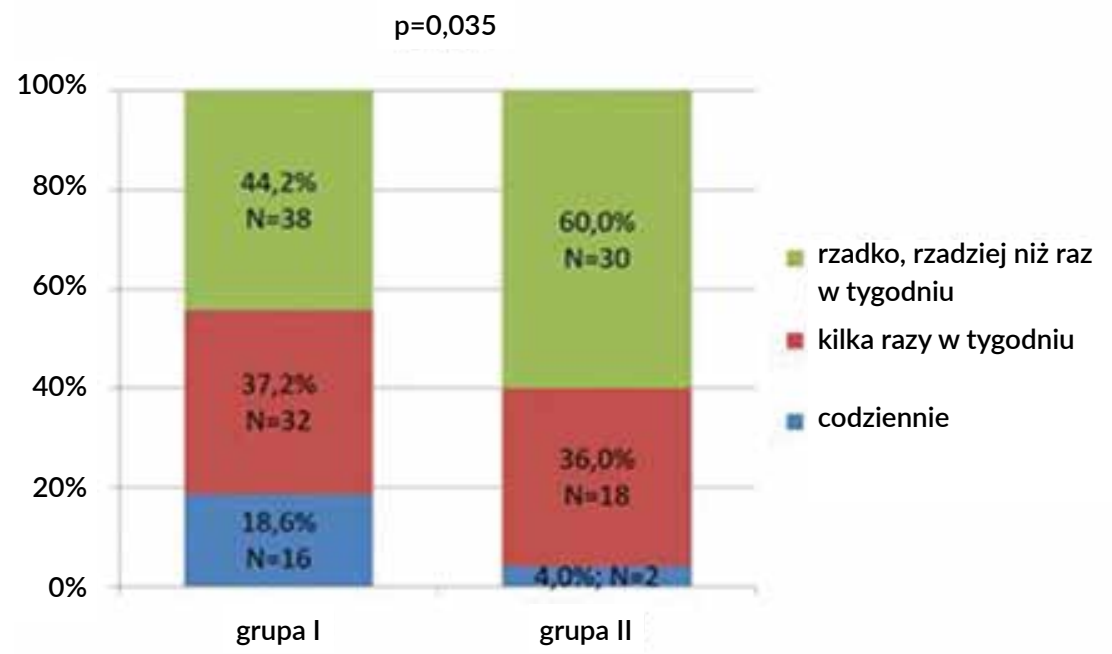

Ryc. 7. Częstość występowania obniżonego nastroju u osób z badanych grup. Źródło własne.

Badane grupy różniły się statystycznie znamiennie $(\mathrm{p}<0,001)$ pod względem dbałości o swój wygląd zewnętrzny. Dla 34,9 proc. badanych z grupy I dbałość o wygląd zewnętrzny nie była ważna, zaś w grupie II wszystkie osoby dbały o swój wygląd zewnętrzny. 36 proc. $z$ nich dbało o wygląd, nie przywiązując do tego dużej wagi, a dla 60 proc. wygląd zewnętrzny był ważny. W grupie I wygląd zewnętrzny był bardzo ważny dla 27,9 proc. osób.

Kwestionariusz Oswestry w szczegółowych pytaniach dotyczących czynności dnia codziennego różnicował badane grupy w czynnościach takich jak siedzenie $(\mathrm{p}=0,014)$, życie towarzyskie $(\mathrm{p}=0,006)$ i podróżowanie $(\mathrm{p}=0,026)$ (ryc. 8). Pozostałe czynności dnia codziennego ujęte w kwestionariuszu Oswestry nie różnicowały badanych grup (ryc. 8).

Nie stwierdzono statystycznie znamiennych różnic pomiędzy badanymi grupami w ograniczeniu funkcjonalności dnia codziennego. Średnie ograniczenie funkcjonalności w grupie I wynosiło 39,4 proc., a w grupie II 32,2 proc. (Tab. 1).

Tab. 1. Ograniczenie funkcjonalności wg Oswestry w badanych grupach osób. Źródło własne.

\begin{tabular}{|c|c|c|c|c|c|c|}
\hline \multirow[t]{2}{*}{ Grupa } & \multicolumn{5}{|c|}{$\begin{array}{c}\text { Ograniczenie funkcjonalności wg Oswestry } \\
\text { wyniki przeliczone do } \%\end{array}$} & \multirow{2}{*}{$\begin{array}{c}\text { Istotność } \\
\text { różnic }\end{array}$} \\
\hline & średnia & odch. std & $\mathrm{Me}$ & $\min$. & $\max$. & \\
\hline 1 & 39,4 & 26,8 & 35,6 & 0,0 & 93,3 & \multirow{2}{*}{ NS } \\
\hline 2 & 33,2 & 17,6 & 33,3 & 2,2 & 71,1 & \\
\hline
\end{tabular}

Jakość życia osób w badanych grupach oceniano za pomocą kwestionariusza WHOQOL-BREF. Dwa pierwsze pytania kwestionariusza WHOQOL-BREF dotyczą zadowolenia z jakości życia i zadowolenia ze swojego stanu zdrowia, ocenianych w 5-punktowej skali, przy czym im wyższa wartość oceny, tym badany jest bardziej zadowolony. 


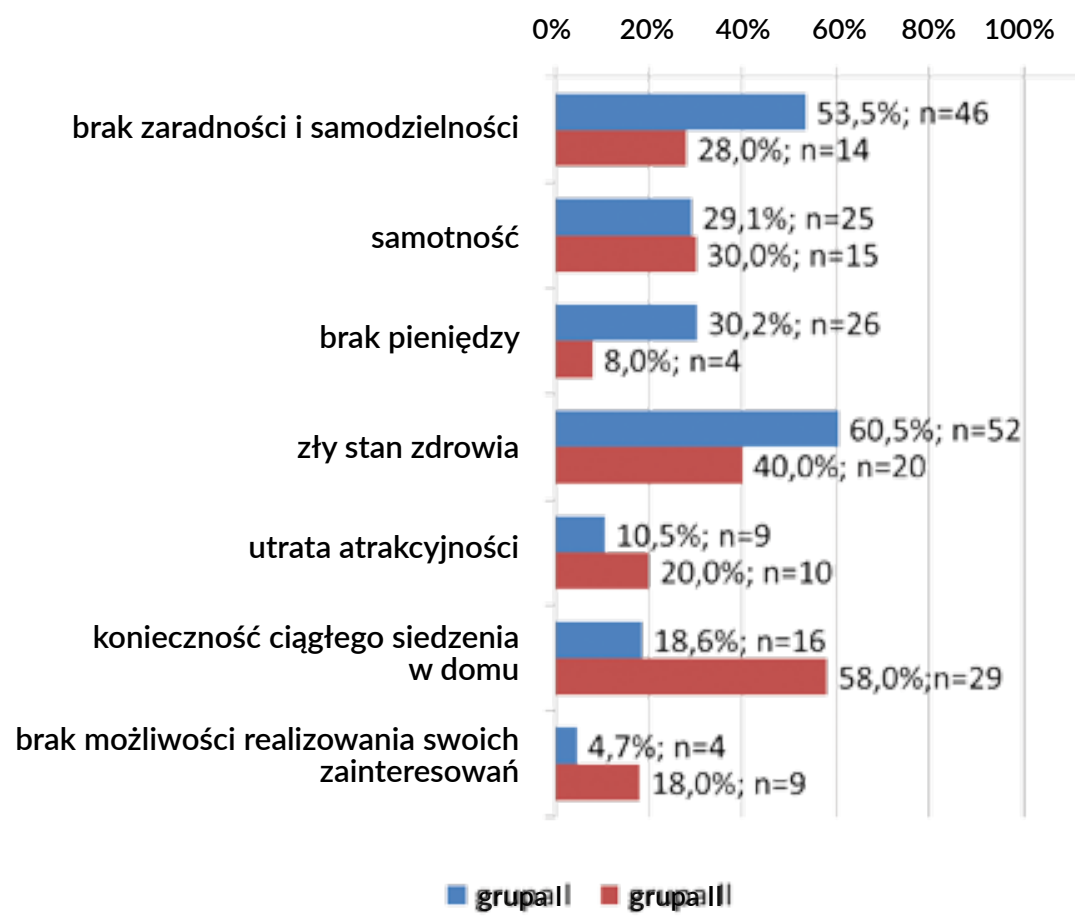

Ryc. 8. Wyniki szczegółowe badania kwestionariuszem Oswestry u osób w badanych grupach. Źródło własne.

Osoby z grupy I postrzegały swoją jakość życia znamiennie $(\mathrm{p}<0,001)$ gorzej (2,97 pkt.) niż osoby z grupy II (3,64 pkt). Ocena własnego zdrowia nie różnicowała badanych grup i kształtowała się na poziomie 3 pkt w 5-punktowej skali (Tab. 2).

Tab. 2. Własna ocena jakości życia i stanu zdrowia w badanych grupach. Źródło własne.

\begin{tabular}{|c|c|c|c|c|c|c|c|}
\hline & \multirow{2}{*}{ Grupa } & \multicolumn{5}{|c|}{$\begin{array}{l}\text { Oceny subiektywne badanych } \\
\text { (skala 5-punktowa) }\end{array}$} & \multirow{2}{*}{$\begin{array}{c}\text { Istotność } \\
\text { różnic }\end{array}$} \\
\hline & & średnia & odch. std & $\mathrm{Me}$ & $\min$. & $\max$. & \\
\hline \multirow{2}{*}{$\begin{array}{l}\text { postrzeganie } \\
\text { jakości życia }\end{array}$} & 1 & 2,97 & 0,86 & 3,00 & 1,00 & 5,00 & \multirow{2}{*}{$\mathrm{p}<0,001$} \\
\hline & 2 & 3,64 & 0,56 & 4,00 & 2,00 & 5,00 & \\
\hline \multirow{2}{*}{$\begin{array}{l}\text { ocena własnego } \\
\text { zdrowia }\end{array}$} & 1 & 3,06 & 0,90 & 3,00 & 1,00 & 5,00 & \multirow{2}{*}{ NS } \\
\hline & 2 & 3,30 & 0,76 & 3,00 & 2,00 & 5,00 & \\
\hline
\end{tabular}

Badane grupy nie różniły się pod względem jakości życia w dziedzinie fizycznej, która występowała na średnim poziomie 45,5-48,2 pkt. Jakość życia w dziedzinie relacji społecznych również nie różnicowała badanych grup, a średni poziom jakości życia w tej dziedzinie w zależności od grupy wynosił 41,1 pkt. i 46,7 pkt. Jakość życia w dziedzinie 
psychologicznej była znamiennie ( $\mathrm{p}=0,004)$ wyższa w grupie II, w której średni poziom wynosił 52,2 pkt, zaś w grupie I 45,2 pkt.

W dziedzinie środowiskowej jakość życia osób z grupy II była znamiennie $(\mathrm{p}<0,001)$ wyższa niż w grupie I. Jakość życia w dziedzinie środowiskowej wynosiła średnio w grupie I 49,8 pkt., a w grupie II 61,6 pkt. (Tab. 3).

Tab. 3. Jakość życia w czterech dziedzinach wg kwestionariusza Oswestry w badanych grupach. Źródło własne.

\begin{tabular}{|c|c|c|c|c|c|c|c|}
\hline Dziedzina życia & Grupa & \multicolumn{5}{|c|}{$\begin{array}{c}\text { Jakość życia wg WHQOL-BREF } \\
\text { (wyniki przeliczone do 100-punktowej skali) }\end{array}$} & $\begin{array}{l}\text { Istotność } \\
\text { różnic }\end{array}$ \\
\hline \multirow{2}{*}{ fizyczna } & 1 & 45,5 & 10,4 & 44,0 & 13,0 & 69,0 & \multirow{2}{*}{ NS } \\
\hline & 2 & 48,2 & 8,5 & 44,0 & 38,0 & 63,0 & \\
\hline \multirow{2}{*}{ psychologiczna } & 1 & 45,2 & 15,7 & 44,0 & 19,0 & 150,0 & \multirow{2}{*}{$\mathrm{p}=0,004$} \\
\hline & 2 & 52,2 & 8,9 & 50,0 & 31,0 & 69,0 & \\
\hline \multirow{2}{*}{$\begin{array}{l}\text { relacji } \\
\text { społecznych }\end{array}$} & 1 & 41,1 & 18,8 & 44,0 & 0,0 & 75,0 & \multirow{2}{*}{ NS } \\
\hline & 2 & 46,7 & 14,8 & 44,0 & 19,0 & 81,0 & \\
\hline \multirow{2}{*}{ środowiskowa } & 1 & 49,8 & 16,0 & 50,0 & 13,0 & 81,0 & \multirow{2}{*}{$\mathrm{p}<0,001$} \\
\hline & 2 & 61,6 & 12,0 & 63,0 & 31,0 & 81,0 & \\
\hline
\end{tabular}

Jak widać, jakość życia badanych osób we wszystkich czterech dziedzinach występowała na poziomie nie niższym niż 40 pkt. i nie wyższym niż 62 pkt., co świadczy o przeciętnym poziomie jakości życia badanych osób bez względu na grupę, do której zostały zakwalifikowane.

\section{Dyskusja}

Badaniem objęto osoby obu płci, w liczbie 136, mieszkające w mieście oraz na wsi. Miejsce zamieszkania różnicowało statystycznie znamiennie $(\mathrm{p}<0,001)$ badane grupy. W grupie I przeważały osoby mieszkające na wsi (64 proc.), a w grupie II osoby mieszkające w mieście (78 proc.). Pod względem wykształcenia w grupie II połowa badanych miała wykształcenie średnie, a druga połowa badanych wykształcenie wyższe. W grupie I przeważało wykształcenie zawodowe ( 38,4 proc.) i podstawowe ( 31,4 proc.).

$\mathrm{W}$ grupie II znamiennie $(\mathrm{p}<0,001)$ więcej osób niż w grupie I chodziło do kina, teatru lub opery. Natomiast w grupie I więcej osób interesowało się przyrodą. i najczęstszym sposobem spędzania wolnego czasu było oglądanie telewizji (45,3 proc. badanych), podczas gdy w grupie II połowa badanych wypełniała czas wolny, czytając książki.

Osoby z grupy I miały ograniczone możliwości korzystania z zajęć lub spotkań dla osób starszych, organizowanych w miejscu zamieszkania, w porównaniu z osobami z grupy II. Seniorzy nie uczestniczą w zajęciach dlatego, że nie chcą, wręcz przeciwnie - osoby 
starsze chcą rozwijać swoje zainteresowania, ale często, mieszkając na wsi czy obrzeżach miasta, mają utrudniony dostęp do takich form aktywności intelektualnej i społecznej ${ }^{19}$. Badane grupy różniły się oceną kontaktów z innymi ludźmi. Prawie wszystkie osoby (94 proc.) z grupy II uważały, że rozmowa z innymi ludźmi poprawia im samopoczucie, podczas gdy w grupie I tak myślących osób było 66,3 proc. W tej grupie 24,4 proc. osób twierdziło, że nie ma okazji, by spotykać się z ludźmi, a 8 (9,3 proc.) osób woli spędzać czas w swoim towarzystwie. W grupie I znamiennie $(\mathrm{p}=0,034)$ więcej osób $(75,6$ proc.) miało problemy z obsługą komputera lub korzystaniem $\mathrm{z}$ internetu niż w grupie II (58 proc.). Obsługa bankomatu, który jest wyspecjalizowanym terminalem komputerowym, stwarzała problemy 64 proc. osobom z grupy I i tylko 22 proc. badanym z grupy II.

Ważną składową jakości życia seniorów jest poziom ich marginalizacji przez młodsze pokolenie. Prowadzenie przez osoby starsze aktywnego trybu życia w dużej mierze zapobiega temu procesowi. Odczuwanie dyskryminacji w traktowaniu osób starszych w życiu codziennym różnicowało statystycznie znamiennie $(\mathrm{p}=0,016)$ badane grupy. Dyskryminacji, braku szacunku, lekceważącego traktowania, wyśmiewania doświadczyło więcej badanych z grupy I. Potwierdza to również praca Haliny ZielińskiejWięczkowskiej - według jej badań aż 85 proc. studentów UTW na pytanie, czy spotkali się z dyskryminacją, odpowiedziało przecząco ${ }^{20}$.

Obawy przed niepełnosprawnością w przyszłości występowały u 53,5 proc. osób z grupy I i 28 proc. z grupy II. Największe różnice pomiędzy badanymi grupami występowały w zakresie obaw dotyczących braku pieniędzy $(\mathrm{p}=0,003)$ i konieczności ciągłego siedzenia w domu $(\mathrm{p}<0,001)$. Braku pieniędzy częściej obawiały się osoby z grupy I, natomiast konieczności ciągłego siedzenia w domu częściej obawiały się osoby z grupy II. Złego stanu zdrowia częściej obawiały się osoby z grupy I niż z grupy II. Zapytano badanych o to, czy chcieliby zmienić coś w swoim życiu. Osoby z grupy I znamiennie $(\mathrm{p}=0,036)$ częściej niż osoby z grupy II odczuwały potrzebę zmian w swoim życiu. W grupie I badane osoby częściej czuły się starsze niż były w rzeczywistości, natomiast młodziej niż w rzeczywistości częściej czuły się osoby w grupie II. Poczucie własnego wieku wśród słuchaczy UTW badała również dr n. med. Halina Zielińska-Więczkowska, gdzie wśród 80 słuchaczy UTW 93 proc. czuło się adekwatnie do swojego wieku lub młodziej ${ }^{21}$.

Pogarszanie się stanu emocjonalnego oraz problemy w funkcjonowaniu w społeczeństwie skutkują większym ryzykiem występowania stanów depresyjnych, które często towarzyszą procesowi starzenia $\operatorname{się~}^{22}$. Powodem depresji występującej po 60. roku życia jest często poczucie braku zaradności w trudnych sytuacjach. Codziennie lub kilka razy

19 B. Szatur-Jaworska, Ludzie starzy i starość w polityce społecznej, Warszawa 2000; P. Błędowski, Lokalna polityka społeczna wobec ludzi starych, Warszawa 2002.

20 H. Zielińska-Więczkowska, Jakość starzenia się i starości w subiektywnej ocenie słuchaczy Uniwersytetu Trzeciego Wieku, „Gerontologia Polska” 17 (2009) 3, s. 137-142.

21 H. Zielińska-Więczkowska, Jakość starzenia się i starości w subiektywnej ocenie słuchaczy Uniwersytetu Trzeciego Wieku, „Gerontologia Polska” 17 (2009) 3, s. 137-142.

${ }^{22}$ K. Faleńczyk, B. Cegła, R. Ślusarz, K. Kędziora-Kornatowska, Wpływ wybranych czynników socjo-demograficznych na występowanie depresji u osób w wieku podeszłym, w: Leczenie, pielegnowanie, zarządzanie - wybrane elementy opieki nad pacjentem, red. J. Konieczny, Z. Bartuzi, Bydgoszcz 2006, s. 494-499. 
w tygodniu obniżony nastrój występował u ponad 50 proc. badanych z grupy I, podczas gdy w grupie II z taką częstotliwością obniżony nastrój występował tylko u 40 proc. badanych. Związek między występowaniem stanów depresyjnych a poczuciem koherencji wykazała w swoich badaniach dr n. med. Halina Zielińska-Więczkowska, badając tę zależność u słuchaczy UTW. Wyniki jej pracy wskazywały, że 72 proc. respondentów nie przejawiało obniżonego nastroju ${ }^{23}$.

Dla 34,9 proc. badanych z grupy I dbałość o wygląd zewnętrzny nie była ważna, zaś w grupie II wszystkie osoby dbały o swój wygląd zewnętrzny. 36 proc. z nich dbało wygląd, nie przywiązując do tego dużej wagi, a dla 60 proc. wygląd zewnętrzny był ważny.

Kwestionariusz Oswestry w szczegółowych pytaniach dotyczących czynności dnia codziennego różnicował badane grupy w czynnościach takich jak siedzenie $(\mathrm{p}=0,014)$, życie towarzyskie $(\mathrm{p}=0,006)$ i podróżowanie $(\mathrm{p}=0,026)$. Pozostałe czynności dnia codziennego ujęte w kwestionariuszu Oswestry nie różnicowały badanych grup. Nie stwierdzono statystycznie znamiennych różnic pomiędzy badanymi grupami w ograniczeniu funkcjonalności dnia codziennego. Średnie ograniczenie funkcjonalności w grupie I wynosiło 39,4 proc., a w grupie II 32,2 proc.

Osoby z grupy I postrzegały swoją jakość życia znamiennie $(\mathrm{p}<0,001)$ gorzej $(2,97$ pkt.) niż osoby z grupy II (3,64 pkt.). Odmienne wyniki uzyskała w swojej pracy Danuta Kozieł, badając zależność pomiędzy kształceniem na uniwersytecie trzeciego wieku a jakością zdrowia, według których na podstawie analizy statystycznej stwierdzono brak zależności w ocenie jakości życia pomiędzy 120 badanymi uczestniczącymi w zajęciach UTW a 65 osobami niepodejmującymi tej aktywności ${ }^{24}$.

Ocena własnego zdrowia nie różnicowała badanych grup i kształtowała się na poziomie 3 pkt. w 5-punktowej skali. Poziom wykształcenia nie ma więc znaczącego wpływu na ocenę stanu zdrowia przez respondentów - podobne wyniki uzyskali Olga Gajewska, Marek Bryła i Irena Maniecka-Bryła - zawarli je w pracy Samoocena stanu zdrowia uczestników zajęć Stowarzyszenia Uniwersytetu Trzeciego Wieku, z której wynika, że ocena stanu zdrowia wśród słuchaczy nie wynika z poziomu wykształcenia, lecz $\mathrm{z}$ ich wieku ${ }^{25}$.

Jakość życia w dziedzinie środowiskowej wynosiła średnio w grupie I 49,8 pkt., a w grupie II 61,6 pkt.

${ }^{23}$ H. Zielińska-Więczkowska, Poczucie koherencji a występowanie stanów depresyjnych u słuchaczy Uniwersytetu Trzeciego Wieku, „Psychogeriatria Polska” 6 (2009) 3, s. 141-146.

24 D. Kozieł, Kształcenie na Uniwersytecie Trzeciego Wieku a jakość życia seniorów, „Gerontologia Polska” 15 (2007) 3, s. 104-108.

25 O. Gajewska, M. Bryła, I. Maniecka-Bryła, Samoocena stanu zdrowia uczestników zajęć Stowarzyszenia Uniwersytetu Trzeciego Wieku, „Hygeia Public Health” 47 (2012) 4, s. 453-459. 


\section{WNIOSKI}

1. Jakość życia badanych osób we wszystkich czterech dziedzinach występowała na poziomie przeciętnym bez względu na grupę, do której zostały zakwalifikowane. Średni profil jakości życia w grupie słuchaczy UTW był nieco wyższy.

2. Osoby starsze nieuczestniczące w zajęciach UTW postrzegały swoją jakość życia znamiennie gorzej niż słuchacze UTW. Badani nienależący do społeczności UTW $\mathrm{w}$ większości zamieszkiwali tereny wiejskie, co utrudniało im korzystanie z tej formy aktywności.

3. Jakość życia w dziedzinie psychologicznej i w dziedzinie środowiskowej była znamiennie wyższa w grupie słuchaczy UTW. Osoby starsze nieuczestniczące w zajęciach UTW częściej niż słuchacze UTW odczuwali: obniżony nastrój, dyskryminację z racji starszego wieku, lekceważące traktowanie oraz potrzebę zmian w swoim życiu.

4. Słuchacze UTW obawiali się o swoją przyszłość w aspekcie konieczności ciągłego siedzenia w domu, natomiast obecnie subiektywnie czuli się młodsi, dbali o swój wygląd zewnętrzny, w czasie wolnym chodzili do kina, teatru, czytali książki.

5. Osoby starsze nieuczestniczące w zajęciach UTW obawiały się: braku pieniędzy, złego stanu zdrowia, niepełnosprawności, braku zaradności w przyszłości, co ma związek z szybko rozwijającą się technologią.

\section{LITERATURA}

Bielawska A. i in., Uniwersytet trzeciego wieku - edukacja zawsze na czasie, „Nowiny Lekarskie” 81 (2012) 1, s. 80-82.

Błędowski P., Lokalna polityka społeczna wobec ludzi starych, Warszawa 2002.

Borczyk W., Wnuk W., Edukacja w starości i do starości, w: Strategie działania w starzejącym się społeczeństwie. Tezy i rekomendacje. Rzecznik praw obywatelskich, Warszawa 2012, s. 78-81.

Faleńczyk K. i in., Wplyw wybranych czynników socjo-demograficznych na występowanie depresji u osób $w$ wieku podeszłym, w: Leczenie, pieleggnowanie, zarządzanie - wybrane elementy opieki nad pacjentem. red. J. Konieczny, Z. Bartuzi, Bydgoszcz 2006, s. 494-499.

Gajewska O., Bryła M., Maniecka-Bryła I., Samoocena stanu zdrowia uczestników zajęć Stowarzyszenia Uniwersytetu Trzeciego Wieku, „Hygeia Public Health” 47 (2012) 4, s. 453-459.

Głębocka A., Szarzyńska M., Wsparcie społeczne a jakość życia ludzi starszych, praca oryginalna, „Gerontologia Polska” 13 (2005) 4, s. 255-256.

Grzegorczyk J., Kwolek A., Bazarnik K., Jakość życia osób mieszkających w domach pomocy społecznej i stuchaczy uniwersytetu trzeciego wieku, „Przegląd Medyczny Uniwersytetu Rzeszowskiego" (2007) 3, s. 225-226.

Izdebski P., Polak A., Bilans życia i poczucie koherencji osób starszych w zależności od ich aktualnej sytuacji życiowej, „Gerontologia Polska” 13 (2005) 3, s. 188-189.

Kałużny R., Aktywność edukacyjno-zawodowa seniorów forma zagospodarowania czasu na emeryturze, „Edukacja Dorosłych” (2014) 2, s. 79-90. 
Kozieł D., Kształcenie na Uniwersytecie Trzeciego Wieku a jakość życia seniorów, „Gerontologia Polska" 15 (2007) 3, s. 104-108.

Lubryczyńska K., Warszawskie Uniwersytety Trzeciego Wieku, http://www.e-mentor.edu.pl/ artykul/index/numer/9/id/148 (25.11.2017).

Marchewka A., Jungiewicz M., Aktywność fizyczna w młodości a jakość życia w starszym wieku. „Gerontologia Polska” 16 (2008) 2, s. 127-129.

Mossakowsska M., Więcek A., Błędowski P., Aspekty medyczne, psychologiczne, socjologiczne, i ekonomiczne starzenia się ludności w Polsce, Poznań 2012.

Ostrzyżek A., Marcinkowski J. T., Wymiary jakości życia w podeszłym wieku, „Problemy Higieny i Epidemiologii" 90 (2009) 4, s. 465-467.

Pasik M., Wyznaczniki jakości życia u osób w wieku emerytalnym, „Acta Univeritatis Lodiensisfolia Psychologica" (2005) 9, s. 71-72.

Richert-Kaźmierska A., Forkiewicz M., Kształcenie osób starszych w koncepcji aktywnego starzenia się, „Studia Ekonomiczne” 131 (2013), s. 128-130.

Szatur-Jaworska B., Ludzie starzy i starość w polityce społecznej, Warszawa 2000.

Trempała J., Zając-Lamparska L., Postawy wobec osób starszych: różnice międzypokoleniowe, „Przegląd Psychologiczny” 50 (2007) 4, s. 448-451.

Trojanowska A., Znaczenie badań nad jakościa życia w medycynie, „Zdrowie Publiczne” 121 (2011) 1, s. 100-102.

Wojtyna E., Dosiak M., Życińska J., Wpływ wsparcia społecznego na przebieg zaburzeń depresyjnych u pacjentów w podeszłym wieku, „Psychogeriatria Polska” 4 (2007) 1, s. 18-19.

Zadworna-Cieślak M., Ogińska-Bulik N., Zachowania zdrowotne osób w wieku senioralnym rola optymizmu, „Psychogeriatria Polska” 10 (2013) 4, s. 145-147.

Zielińska-Więczkowska H., Jakość starzenia się i starości w subiektywnej ocenie słuchaczy Uniwersytetu Trzeciego Wieku, „Gerontologia Polska” 17 (2009) 3, s. 137-142.

Zielińska-Więczkowska H., Kędziora-Kornatowska K., Determinanty satysfakcji życiowej w późnej dorosłości - w świetle rodzimych doniesień badawczych, „Psychogeriatria Polska” 7 (2010) 1, s. 13-15.

Zielińska-Więczkowska H., Poczucie koherencji a występowanie stanów depresyjnych u słuchaczy Uniwersytetu Trzeciego Wieku, „Psychogeriatria Polska” 6 (2009) 3, s. 141-146.

Ziębińska B., Uniwersytety Trzeciego Wieku - wybrane aspekty funkcjonowania organizacji, „Polityka Społeczna” (2009) 3, s. 21-22. 